\title{
Interface Between History and Drama and Nation Building: A Marxist Reading of Femi Osofisan's Morountodun
}

\author{
${ }^{1}$ Taiwo A. Stanley Osanyemi, ${ }^{2}$ R.E Iwuanjoku and ${ }^{3}$ F.B. Awotayo \\ ${ }^{1,2,3}$ Department of General Studies-School of Business Studies- Federal Polytechnic-Nigeria \\ ${ }^{1}$ taistanley@yahoo. com
}

\begin{abstract}
The thrust of this paper is the proclivity that history and drama are essential ornaments in nation building as depicted in Femi Osofisan's Morountodun. When drama is stimulated by history, it responds in an effective way by recreating reality and turning it into fiction. Existing scholarly engagements on history and drama tend to disconnect them as two parallel lines but this paper rethinks this position by aligning them as complements for the actualization of the ideals in human society. It examines the complementary roles of the nexus between history and drama as nation builders. Our primary data is Femi Osofisan's Morountodun which is subjected to critical textual analysis. It draws inspiration from Karl Marx's theory that reveals class struggles and conflicts in order to address the poignant socio-political predicaments in human society. It concludes that the playwright's cultural and ideological tilts prompt his use of historical materials as catalyst for change and positive growth of a nation.
\end{abstract}

Keywords: History, Drama, Interface, Growth, Nation

\section{Introduction}

History and drama perform similar basic function: they record human experiences to educate the living as well as posterity. Rex Daniel (2003) defines history as the 'memory of human group experience' (17). Obaro Ikime (2005) stresses that if such a memory of human experience is forgotten or ignored, then, people will cease in that measure to be human. Thus, without history, there would be no knowledge of who a people are, and how they have come to be, like victims of collective amnesia groping in the dark of identity.

History does not only deal with memory of the past, it also has a link with the present. In this regard, Fadeiye (2010) sees history as an attempt to rethink the past (2). It inquires into the past in terms of what happened, when it happened and how it happened. It equally examines the developments and changes that have occurred in different human societies in the past and how such changes affect, influence and determine the present conditions of life in the society. Although, history has been the study of the past, however, the past is not 'dead' rather, it is constantly impinging on the present (Wayne, 2006). Harry Lee (1993) supports this assertion that people cannot escape from the past as the past is built into the concepts employed to cope with the everyday physical and social world. It will be suffice to see history as a dialogue between the past and the present for future building.

However, Charles Adesina (2012) provides a comprehensive and utilitarian definition of history as:

total embodiment of humanistic studies that piercingly look into the global spread of ideas and cultures, the conflict between global citizenship and national citizenship, the interface of national interest and global interest, the issue of national sovereignty, poverty. The sharpening of ethnic and religious fault lines, territorial disputes, transnationalism interpretation of values and host of others. (4) 
the glaring point in this definition is that it is the duty of history and historian to connect all the issues mentioned with the society to make sense of their existence in a world of great flux. Howard Handelman (2006) shows the importance of the social and economic roles of history by seeing history as a necessary study "which will attend to the need to understand the nature and causes of underdevelopment which has trapped our countries in a political and economic quagmire" (5). It is obvious that poverty, ethnic tensions, massive human suffering and poor public policy have adversely affected social conditions in developing countries like Nigeria. All these have been narrowing the opportunities for human development and according to Handelman, history has a place to ameliorate them. The point is, history as a field of study and phenomenon, needs to be engaged seriously as people are anxious to make a sense of their conditions in this dysfunctional continent that is rich in human and natural resources. There is an increasing need to expand the framework of history to interrogate the lack of sustainable progress.

On the need for recourse to history and historian on national building and development, Richard Olaniyan (2018) opines thus:

\section{The decision to embark upon the critical examination of an issue that is indisputably topical and contemporary, and may indeed, in several respects, be controversial was borne out of the conviction that the historical profession has both a professional and civic responsibility to pay attention to issues and developments considered relevant and germane to the life and well-being of the society.(6)}

It is quite unfortunate that in some parts of Africa, the government is often skeptical about whether the historian can say anything of interest to persons or nations grappling with contemporary problems of socio-economic growth and advancement. Olaniyan (2018) further that explains the jeopardy that persons and nations that ignore history and historians will find themselves, with Nigeria and her people as examples, Olaniyan has this to say "no wonder we are trapped in a maze, we are running around in circles looking for escape routes from our self-imposed prisons" (7). The probable solution to these crises is in careful examination with diligence of the past, if we examine the past with diligence, it is easy to foresee the future of any commonwealth, and to apply those remedies which were used of old; or, if we do not find that remedies were used, to devise new ones owing to the similarity between events. Therefore, the task of the historian is, to study and interpret the changes embodied in society and explain the reasons for them. In the process, the society will be able to gain self-knowledge and clearer appreciation of its past and its present as basis for anticipating its future.

John Lonsdale (1989) abrogates the role of historians as people who cannot but judge the human successes and failures which they find in their recreation of the past other than by the light of their own hopes and fears for the future (127). From this perspective, one is brought to the realization that the past has an overwhelming influence on the present and future. This agrees with Leo Berg's (2001) position that historical research extends beyond a mere collection of incidents, facts, dates or figures, but is the relationship among issues that have influenced the present and will certainly affect the future. Having seen the relevance of history and survival of human society, it will be expedient before textual engagement to traverse the significance of history to drama.

\section{The Significance of History to Drama}

Drama is a product of social life like the other genres of literature. It is truthful that the dramatist selects material for his or her creative output from happenings in real life which is the hallmark of history. History, therefore, is a veritable source for playwriting. In this sense, the dramatist, according to Toyin Jegede (1998) becomes a prophet - seer who foresees and foretells the future. However, she posits further that the structure of a fiction differs from that of history in 
that fiction relates a causal between events, while history relates the temporal relation of events. The historian relates what has happened, the dramatist reveals why events might happen. The dramatist does this by incorporating the causal elements of character and motivation into the representation of events. She (Jegede) sees history as records of the particularities of an action or event while drama embraces its universals which are the knowable causes of particulars.

Victoria Adeniyi (2007) comments on the interrelatedness of history and drama when she opines that history that is written in form of drama is on a higher plane, more intense, more universal and more philosophical than history which is written in a chronological manner and is more important. Thus, it can be said that historical drama deals with a particular point in the history of the society. It gives insight into what life was like at the particular period chosen by the playwright as focus. Adeniyi further explains that history, just as politics is the crucible that shapes the ideological sensibilities of dramatists.

Looking at the affinity between dramatist and historian, Femi Osofisan (2001) opines that similarity of purpose unites the playwright and historian, both apparently feeding as contemporaries fashioned by and responding to the same historical mutations from essentially the same sources. This is succinct to say that both are on-going re-assessment of what happened in the past and the implication for the present as well as the future. Greg Dening (1993) buttresses this claim when he posits that history is not the past, it is a consciousness of the past for present and future purposes. The genesis of historical drama springs from a shift from the recreation of oral tradition in dramatic terms to the re-creation of a past contained in written histories (Etherton, 1979). Underscoring the import of history into drama, Wole Soyinka (2006) posits that" the purpose of existence of drama, we exist is enquiry, and enquiry encompasses past, present and future" (6). From Soyinka, the essence of historical drama is to learn from the past to build the future. Therefore, remarkable deeds of the past (histories) should not be ignored or forgotten as Gbemisola Adeoti (2007) reiterates that though, man may forget the past as documented in history, history hardly forgets man and that accounts for the tendency for repetitiveness of human history (33).

From the above, it can be inferred that historical playwrights not only seek to dramatize history but also to redefine it, interrogate it, intensify it and draw a connection overtly or covertly between the past and the present with a view to shaping the course of future actions in nation building. James Ngugi (1981) comments that drama (either historical or not) cannot elect to stand alone or to transcend economics, politics, class and race. From Ngugi's argument, it is clear that drama cannot escape the social and political happenings of its time which constitute the history of the society. Moreover, it is clear that a historical dramatist cannot escape being partisan as he takes ideological positions, since he is producing from real life which is ideologically and politically divided or lopsided. The point to bear in mind is that, historical dramatist may not recreate history in his work as it has happened exactly in life but the aim is to harness history as a catalyst for the attainment of societal ideals, better future governance and harmonious co-existence of human being and their world.

It will be pertinent to see the hybrid of history and drama by some literary scholars through the depth of their commitment, ideological leanings and tilts, social visions and dramatic conventions. Notable works whose sources are derived from history include Ola Rotimi's Kurunmi, Ovonramwen, Erelu-Kuti; Ngugi wa Thiong'O and Micere Mugo's The Trials of Dedan Kimathi, among others. In these works, the writers depict aesthetically the social and political realities in their various societies in order to right the existing wrongs. Having seen the nexus of history and drama as an essential praxis from which realities of existence of society can be viewed, we will proceed to textual engagement which will be influenced by Marxist social theory in order to annex and sift out the correlation between the primary text, Morountodun, historical legendary Moremi and the Agbekoya episode in the Western region of Nigeria in 1969. 


\section{Historical Moremi and Fictional Moremi and Nation Building}

The play, Morountodun is based on the Moremi legend of Ile-Ife, it is a dramatic examination of the singular acts of heroism and positive commitment of the protagonist, Titubi, who is the spoilt and over pampered daughter of Alhaja Kabirat, head of the market women. Like other Osofisan plays, the playwright brings into focus Marxist ideology of social conflicts, struggles and stratification based on the state of economy in the society. He exposes the prevalent socio-economic stranglehold in the society and tries to make people aware of the situation. Osofisan exposes the culturally substantiated anomaly that some members of the society should be inferior and servants to others in their fatherland. Morountodun emphatically goes a bit further into history to show the only avenue to a snug tomorrow for every citizen is a violent demonstration, if the class of oppressors fails to consider the poor as this is in line with Karl Marx's advice that if the Bourgeois are not ready to relinquish the power to the masses, they (masses) can force them out of power.

The play opens with Titubi and her followers challenging the right of theatrical company to make people to attack the government in their artistry. Titubi's mother is very rich and this makes it possible for her to assemble a group of vandals who consciences have been bought over by Titubi's mother. Titubi wears a necklace with an inscription of golden effigy or portrait of Moremi, this is a symbol of a rich girl that is unperturbed by the hues and cries of the poor masses, she is not directly affected by the uproar and revolt of masses against their rulers. Her ego makes her to come to the scene of the revolt of the peasant farmers. Her original intention is to add to the suffering of the masses (the peasant farmers) who are disturbing the rich, the class her mother and herself belong to. She has been aware of the heroic deed of historical Moremi of Ile-Ife who infiltrated the camp of the enemy of her society to liberate her people from a disdainful invasion. As she wears a necklace with the portrait of legendary Moremi, she wants to participate in an act of courage and heroism thinking that the peasant farmers are actual enemy of her society like the giant attackers the legendary Moremi outwitted triumphantly in the quest to save her people. Aesthetically, Osofisan, the playwright is presenting two Moremis - the historical and fictional through a fusion of history and drama.

In enacting history with drama, Osofisan presents a capitalist set up to elucidate an act of heroism in an individual, rather than in communal effort. Titubi's freedom from wants propels her into an idealistic adventure instead of achieving her mother's desire of attacking the peasant farmers and by extension the masses, she attacks the anti-peasant forces. What informs this action in her is the sarcastic appellation of Moremi accorded her by the Police Superintendent Salami "this is where you come to put up a gallant fight, wasting my time. Go on, Titu-Titu, the magnificient Moremi of the sixties" (14). The most important thing here, is that Titubi agrees to do this, not for any patriotic reason initially but for adventure which eventually earns her a heroic and indelible accomplishment just like the legendary Ife's Moremi. In Morountodun, Osofisan uses dramatic aestheticism to distort the character of legendary Moremi who is a queen that sacrificed her dignified position to become a captive for her society's sake by fictionally creating a young unmarried, arrogant and saucy Moremi (Titubi) who incidentally shares similarity of purpose with the popular and heroic Ife's Moremi.

In addition history has it that the legendary Moremi is ready to sacrifice herself for the course of patriotism and liberation of her people but Osofisan's Moremi (Titubi) is carefree and not committed to any course, but she flamboyantly displays her parent's wealth around to the consternation of a police officer who rebukes her sarcastically. The rebuke, just like deus ex machina transforms her to become a fanatical supporter of the peasant farmers, a course she detests with passion before. Although, there are some indications that her humanity is aroused when she sees the plight of the peasant farmers (suffering masses), but her initial world view is that of the rich person who does not believe that anybody is poor enough not to be able to afford three square meals. As this is buttressed by Titubi's mother, Alhaja, who challenges the protesters' claims to be 
untrue - "it is a lie! No one has ever died of hunger in this country! I am surprised at you, a police officer, carrying this kind of baseless propaganda" (24).

This response has portrayed Titubi's mother as a capitalist and an oppressor. It depicts her as a callous and unscrupulous person whose sole aim is the gratification of her only needs without any consideration for others (masses). This sounds like a statement credited to a politician during Shagari regime in the defunct Second Republic in Nigeria who publicly and disdainfully says that there is no poverty in Nigeria, after all nobody is seen eating from a dustbin when abject poverty is boldly written in all the nooks and crannies of Nigeria. While Titubi's mother is carried away by her wealth, her society is in the abyss of penury and gross underdevelopment. The situations of her society succinctly become the catalyst for the farmers' revolt as this is aptly captured as:

Our roads have been so bad for years now that we can no longer reach the market to sell our crops. Even your council officials and the akodas harass us minutes by minutes and collect bribes from us. Then they so build mansions in the city... Your Marketing Board seizes our cocoa, and pays us only one third of what it sells to the Oyibo. We have no electricity and we still tanwiji from the stream. Many of our children are in jail for what your people call smuggling (Morountodun, 65)

This statement brings into the focus the conflict in the play which is the dichotomy between the led and their leaders. It vividly portrays the social imbalance in the society which Osofisan is artistically trying to correct. Should this social injustice continue? To answer this, a heroic character is aesthetically created from the rich end, the oppressors of the masses (Titubi) who passionately empathizes with the peasant farmers "you know ... before this ... I could never have believed that life was so unkind to anybody" (65).

This shows that the masses that constitute the major labour force in Nigerian society are neglected while the few rich (leaders) are living in affluence. Awakening from social slumber by the majority labour force is the preoccupation and overwhelming concern of the playwright in Morountodun. This is why he uses Ife history of legendary Moremi and blends it with his fictional Moremi (Titubi) to really expose the wild gap between the rich and poor socially, economically and physically. In spite of the fact that Titubi comes from the rich end, Osofisan transforms her artistically to lead the struggle against the force that oppresses and condemns the masses. This is tantamount to biting a finger that feeds one. The realization of the piteous fate of the masses by Titubi provokes her and she concludes:

\section{I know I had to kill the ghost of Moremi in my belly. I am not Moremi, Moremi served the state, was the state, was the spirit of the ruling class. But it is not true that the state is always right (Morountodun, 20)}

Unbelievably, the hunter has become the hunted. A quest and lust for adventure has turned the heroine into the rite of passage. She is able to see things that have been shrouded from her since childhood. Her conscience strongly identifies with the suffering masses, she chooses to be on the side of the oppressed people. She sacrifices all the wealth in her family at the altar of selflessness and altruism as she flings Alhaja Kabirat's (her mother) wealth into her face because she has just gotten a renewed conscience.

Morountodun, as a play interrogates history through characterization, characters like Marshall, Baba, Bogunde, Mosun, Kokondi and others are historical personages - the warriors in Alafin Abiodun's palace during Agbekoya (farmers revolt) of 1969 in the Western Region of Nigeria. They seek to free their minds from the shackles of oppression. They are equally deprived and closer to the farmers. The farmers toil all days on the farm, tending crops that are not eaten by them. They do not even get enough money from their labour. They travel on bad roads, carrying their food and cash crops to the city. They neither have pipe-borne water nor electricity supply. Yet bribe-infested 
sanitary inspectors have it over them, harassing them at will until they pay an amount of money which never gets into government's coffers. So, also tax collectors are not able to afford to pay exorbitant tax they charge the peasant farmers.

In an unending catalogue of economic and social deprivation, the farmers have nowhere to turn to; their sons in the cities have also betrayed them. This is seen in the roles characters like Lawyer, Isaac and Alhaji Buraimoh (the farmers' children) play in the play. These characters have no consideration whatsoever for the peasant farmers who till the land to train them but ironically they neglect them during decision making at both legislative and executive arms of the government and they ignore their agitation for better living conditions. These farmers have been so discriminated that they find it difficult to see themselves as parts of the intricate machinery referred to as government. Government officials have been so indifferent and inhuman to them that these farmers now see government as an inanimate thing that is devoid of human feelings and sensibilities. After all, these farmers are law abiding citizens who pay their tax but they have not been given commensurate treating by their leaders, there has never be a provision that will improve their farming and better their lot such as provision of free fertilizers or at subsidized rate, soft loans at a reduced interest rate, water irrigation system and others. The only friends of their leaders are the selfish and sycophant politicians like Alhaja Kabirat, Titubi's mother and others who have never known a day suffering; they do not know what suffering is.

This is the background to a social upheaval: a revolution that will destroy class stratification that turns the hard working members of the society into paupers in their fatherland. Their revolt in the play showcases only a logical result of several failed attempts of dialogues with governments agents and the triumph of lackadaisical attitudes of government agents and representatives. This is a miniature of what obtains in the contemporary African state especially Nigeria, where every attempt to sanitize government activities proves abortive. Various labour unions are clamouring for better working conditions but the government remains unperturbed. It has become a popular maxim that 'government only understands violent confrontation not dialogue'. It is from this scenario and the desperate position of the farmers and by extension, the masses that the humanity of Titubi, the fictional Moremi is awakened. She reneges from the oppressive posture of her world and finds solace in the farmers' inclination. She wants her mother to realize this as she advises her "Mama our life itself is not important. Nor all these glittering tinsels we use to decorate it but posterity and conscience" (70). The playwright has aesthetically addressed the past and the present Nigerian society from the nexus between history and his dramaturgy in order to find an ideal tomorrow.

Titubi's affinity for a free and liberated world is not unconnected with Marxist ideology that sees class division as a product of bourgeois because she (Titubi) sees the leaders as substances that cohere social inequality, class struggle and consciousness to the society that God created as single entity. She becomes a hero who is ready to free her society at the detriment of her mother as a result of having heard and referred to as Moremi, the legend and queen of Ile-Ife the ancestral home or source of the Yoruba race in Nigeria.

The reason why Osofisan reinforced individual collectivism is probably because the farmers are productive people in the society. For they provide food for the entire populace, but it is clear to everyone that the profit they make are not substantial and far below what they deserve as a result of indifference they suffer or receive from the government. Their sweat and struggles have gone down the drain while the rich and politicians like Alhaja Kabirat are adding flesh and fat. This situation is highly appalling and frustrating, this is a replica of want the farmers are experiencing in Morountodun and it metamorphoses to Agbekoya (farmers reject hardship) Farmers' Revolt in reality in 1969 in Western Nigeria. The agitating farmers naturally find a significant female character who eventually champions their course at the utmost chagrin of the ruling class. The farmers' agitation stands as the prototype for other unions and organization that clamour for equal distribution of wealth in the nation. Hence, the playwright pitches socialist proletarians against 
capitalist bourgeoisies; the poor against the rich and the led against the leaders as this is what Karl Marx's ideology stands for.

It is quite glaring that this is an actual reflection of the values of Nigerian society. Osofisan has evaluated the socio-economic situation of Nigeria and discovered that it has become a custom that a set of people to exploit the other; for government functionaries to take percentages by a contractor's purse before being awarded contracts; rogues become overnight chieftains; wife grabbing becomes common thing among the rich and rulers. Of course the poor continue to suffer. Among the poorest in Nigerian society are the hardworking peasant farmers who toil from cockcrow to sunset in the farms with little or nothing to show for their intense experience. In this play, the playwright subtly foreshadows a change in the status-quo when the vampires that suck on the blood of toiling citizens would be relieved of their positions of power through the united and cooperative revolt of the masses.

With history and dramatic inclination, the playwright makes an attempt to trace an interrogate the unending picture of exploitation and oppression that has been the lot of African nations right from the era of colonialism to post-colonialism and of course neo-colonialism. It shows that African people have always lived a near-communalist state before the advent of colonialism that puts knife on the cord of unity and oneness among Africans. It is succinctly obvious in Morountodun the use of historical material for a gradual build up for revolutionary social change. The play shows vividly the causes of social ills, the prevalence of selfishness and the get-rich-quick urge of members of our society. Therefore, this is a play about the dehumanizing utility of an unhealthy society. The play as well lambasts the socio-economic deprivation that destroys the good man in our society who has nowhere to turn to for survival and all around him are unscrupulously rich people that have impoverished him and milk-dried the society. The rich are conspicuously worshipped by the poor who cannot fight in order to change their piteous plight orchestrated by the conscientiously callous leaders because poverty has lobotomized. From whichever perspective one looks at the play, it will be seen that past and present socio-economic happenings (histories) play an outstanding role toward the creation of violence, chaos and revolt in Nigerian society.

\section{Conclusion}

From the analysis above, the play, Morountodun has ixed up history with dramatic imagination to prepare ground for the ideal in the society and to usher him a revolution against untoward socioeconomic situations. The playwright has redefined history to teach the upper members of the society how to make lives habitable. Morountodun has overtly revealed its playwright as a social crusader with an anchor on revolution as a necessary tool for reformation in a ruptured society through the rejuvenation of an ancient history of Ile-Ife. The playwright has successfully done this by being apparently Marxist to fight for equal right and equitable distribution of wealth.

From this paper. The history of the legendary Moremi an Ife queen has been refined with Agbekoya Episode of Oyo State in 1969 to seek for a better world of equity and socio-economic balances. This history is fused into drama so that the history of remarkable deeds and characters will not become a placebo but a reminder of good norms and virtue that can actualize good governance and ideal leadership to guarantee blissful future for the society. The interface between history and drama is equally engaged to preserve societal historical past from going into extinction. 


\section{References:}

[1] Adeniyi, Victoria (2007). A Comparative study of Rotimi's Ovonramwen Nogbaisi and Yerima's The Trials of Oba Ovonramwen. Muse and mimesis. Gbemisola Adeoti. Ed. Ibadan: Spectrum. 97-109

[2] Adeoti, Gbemisola (2007). Drama is an arbiter of socio-political crises. Muse and mimesis. Gbemisola Adeoti. Ed. Ibadan: Spectrum. 347-365.

[3] Adesina, O.C. (2012). The future of the past. An inaugural lecture 2011/2012. Ibadan: University of Ibadan Press

[4] L.B. Berg, (2001). Qualitative research methods for the social sciences. Boston: Allyn and Bacon

[5] R.O. Daniel, (1966). Studying history: how and why? London: Eaglewood Cliffs

[6] Dening, Greg (1993). Mr Blight's bad language. Cambridge: Cambridge University Press

[7] Etherton, Michael (1979). Trends in African theatre. African literature today. Vol.10 London:Heinemann 57-85

[8] J.O. Fadeiye, (2010). History and historiography, archaeology and methods of teaching history. Lagos: Murfat Publications

[9] Handelman, Howard (2006). The challenges of third world development, $4^{\text {th }}$ edition. Apper Saddle River. New Jersey: Pearson Education Inc.

[10] Ikime, Obaro (2000). Why teach history? Owerri: Lasen (Nig) Ltd

[11] Jegede, Oluwatoyin (1998). Studying fiction, an introduction to prose narratives. Ibadan: Elp

[12] H.N. Lee, (1973). Percept, concepts and theoretical knowledge, a study in epistemology. Memphis: University Press

[13] Lonsdale, John (1989). Africa's past in Africa's future. Canadian journal of African studies. Vol.23. no.1, 126-146

[14] Ngugi, James (1981). Writers in politics. London: Heinemann

[15] Olaniyan, Richard. (2018). Rich country, poor people: antimonies of the discourse on national development in Nigeria. $2^{\text {nd }}$ Annual University Lecture, Kings University, Ode $\mathrm{Omu}$

[16] Osofisan, Femi.(2001). Insidious Treasons, a collection of Femi Osofisan's essays. Ibadan: Opon Ifa Publisher.

[17] Osofisan, Femi. (2004). Morountodun and other plays. Ikeja: Longman Nigeria Plc.

[18] Soyinka, Wole.(2006). Forget the past, forfeit the future. Zaria: Ahmadu Bello University Press

[19] R.E. Wayne, (2006).The social studies curriculum: purposes, problems and possibilities. New York: SUNY Press. 